\title{
Pelatihan Trik Pemasaran Dengan Meningkatkan Pendapatan Melalui Media Sosial
}

\author{
Dede Suleman $^{1}$, Imelda Sari ${ }^{2}$, Taat Kuspriyono ${ }^{3}$, Dedi Suharyadi ${ }^{4}$ \\ 1,2,3,4 Program Studi Manajemen, Fakultas Ekonomi Dan Bisnis, Universitas Bina Sarana Informatika, \\ Jakarta, Indonesia \\ Email: ${ }^{1} d e d e . d l n @ b s i . a c . i d,{ }^{2}$ imelda.isx@bsi.ac.id, ${ }^{3}$ taat.tat@bsi.ac.id, ${ }^{4}$ dedi.dsi@bsi.ac.id
}

\begin{abstract}
This journal contains the results of research related to training in marketing tricks to increase income with the help of social media. In the current marketing program, efforts to increase income need to be carried out apart from offline sales, it also needs to be done with online activities. One of the obstacles could be the lack of knowledge from the company team in using online marketing methods, especially through social media. Currently the company's marketing activities were previously carried out offline through advertising marketing and other print media in the form of distributing brochures or pamphlets and then continuing with marketing through print media and electronic media. Currently, both types of marketing activities are considered ineffective, especially in the midst of the Covid-19 pandemic, which has not yet ended. The main problems experienced by companies today include low income due to the impact of the pandemic where offline marketing activities are experiencing a pandemic so there needs to be a solution for marketing methods with new methods. One solution that is trying to be delivered in this community service activity is training on the use of social media. could be Instagram. So, it can be said that this could be one of the solutions in digital marketing with more emphasis on the use of social media in marketing products to increase company income.
\end{abstract}

Keywords: Digital Marketing, Social Media, Marketing Strategy.

\begin{abstract}
Abstrak
Jurnal ini berisi tentang hasil penelitian terkait pelatihan trik pemasaran untuk meningkatkan pendapatan dengan bantuan media social. Dalam program pemasaran saat ini upaya peningkatan pendapatan perlu dilakukan selain dari penjualan offline juga perlu dilakukan dengan upaya kegiatan online. Salah satu kendala bisa jadikurangnya pengetahuan dari team perusahaan dalam menggunakan metode pemasaran secara online khususnya melalui media sosial. Saat ini kegiatan pemasaran perusahaan yang sebelumnya dilakukan secara offline melalui pemasaran iklan dan media cetak lainya berupa penyebaran brosur atau pamflet lalu berlanjut dengan pemasaran melalui media cetak dan media elektronik. Saat ini kedua jenis kegiatan pemasaran tersebut dirasa kurang efektif, apalagi ditengah pandemi Covid 19 yang sampai saat ini belum juga berakhir. Permasalahan utama yang dialami perusahaan saat ini antara lain adalah rendahnya pendapatan karena dampak pandemic yang mana aktifitas pemasaran offline mengalami pandemic sehingga perlu ada solusi cara pemasaran dengan metode yang baru, Salah satu solusi yang coba disampaikan dalam kegiatan pengabdian kepada masyarakat ini adalah pelatihan pemanfaatan media social bisa berupa Instagram. Sehingga bisa disebut bahwa ini bisa jadi salah satu solusinya di pemasaran digital denganl ebih ditekankan pada pemanfaatan media sosial dalam memasarkan produk untuk meningkatkan pendapatan perusahaan.
\end{abstract}

Kata Kunci: Pemasaran Digital, Media Sosial, Strategi Pemasaran.

\section{A. PENDAHUluAN}

Dampak pandemic tidak bisa dihindari oleh seluruh sector usaha dimana dalam era pandemic saat ini semua aktifitas perusahaan mengalami keterbatasan karena banyak aturan-aturan yang ditetapkan oleh pemerintah dimana aturan-aturan tersebut berdampak pada pembatasan aktifitas-aktifitas yang bisa dilakukan oleh perusahaan dalam upaya penjualan produk (Suleman et al., 2020b). Salah satu perusahaan yang berdampak tentu perusahaan dimana selama pandemik kinerja dan upaya pemasaran yang dilakukan selama ini tidak berdampak maksimal.

Perubahan cara dan proses penjualan tidak dapat dihindari lagi karena memang perusahaan harus selalu menggunakan metode dan cara baru dalam 
melakukan program promosi (Suleman et al., 2021). Alternatif cara baru perlu dilakukan agar mampu bertahan diera yang ada metode dan stategi pemasaran baru adalah jalan terbaik yang bisa dipilih dalam melakukan program pemasaran yang dilakukan agar dapat mempertahankan pendapatan atau bahkan meningkatkan pendapatan perusahaan seperti sebelumnya (Sumawan, 2002).

Kondisi PPKM saat ini sangat menyulitkan perusahaan dalam usahanya melakukan kegiatan promosi dan menjual produknya secara langsung ke konsumen. Penjualan yang menurun drastis menyebabkan pendapatan yang diterima perusahaan juga berkurang secara drastis. Untuk mempertahankan hidup dan menjaga kelangsungan usahanya maka perusahaan harus mau berinovasi dengan cara melakukan promosi serta menjual produknya secara online pada media social (Kotler et al., 2019). Promosi dan penjualan produk secara online ini jika dilakukan dengan tepat justru akan menghasilkan penjualan yang lebih besar daripada ketika produk dijual secara langsung ke pembeli, karena penjualan secara online ini akan memudahkan pembeli untuk mendapatkan produk dan jasa yang dibutuhkan tanpa harus keluar rumah dan promosi produk secara online juga dapat memperluas daerah pemasaran (Kartajaya \& Marketeers, 2018) . Jika penjualan dapat stabil kembali maka diharapkan pendapatan yang diterima pelaku usaha juga akan meningkat. Kegiatan online tidak dapat dipungkiri karena memang perilaku konsumen sudah berubah ditempat baru yang mana kondisi sudah memaksa mereka untuk menciptkan perilaku baru (Suleman et al., 2020a).

Salah satu upaya yang bisa dilakukan untuk mewujudkan dan mensosialisasikan sistem promosi dan penjualan secara online dimedia sosial, perusahaan diharapkan mengadakan pelatihan untuk meningkatkan pengetahuan dan ketrampilan untuk pemasaran dan agen dari perusahaan dengan melakukan penjualan dengan bantuan media social (Suleman et al., 2019). Yang diharapkan perubahan cara baru ini bisa menjadikan pendapatan perusahaan bisa dijaga seperti sebelum pandemic bahkan diharapkan bisa meningkatkan pendapatan perusahaan dengan cara promosi baru yang dilakukan.

\section{B. PELAKSAAAN DAN METODE}

Metode pelaksanaan yang ditempuh untuk mengatasi permasalahan ini adalah diawali dengan melakukan observasi dan pemberian kuesioner kepada pegawai di perusahaan untuk menentukan presentase tingkat kesulitan dan tingkat kemudahan yang mereka alami dalam memasarkan produk dan jasa yang mereka hasilkan sampai nanti idealnya dilanjutkan kegiatan lanjutan pada tahap membandingkan dengan data sebelum dan sesudah pelaksanaan kegiatan pelatihan penggunaan media social untuk kegiatan promosi.

Kegiatan ini merupakan bentuk pengabdian kepada masyarakat yang diberikan berupa pelatihan pemanfaatan media social yang kita tahu ada beberapa platform media social dengan pengguna terbanyak di Indonesia antar lain : Facebook, Instagram, Youtube, Linked In dan Google My Bussines. Namun dalam kegiatan pengabdian masyarakat ini lebih ditekankan pada pemanfaatan media sosial Instagram untuk memasarkan produk untuk meningkatkan pendapatan perusahaan.

Kegiatan Pengabdian Masyarakat merupakan salah satu bentuk Tri Darma Dosen di lingkungan Perguruan Tinggi. Adapun pelaksanaan kegiatan dilakukan secara virtual menggunakan aplikasi Zoom Meeting mengingat pandemi Covid 19 yang masih melanda dan masih diberlakukannya PPKM oleh pemerintah sedangkan materi yang akan disampaikan berkaitan dengan Trik Pemasaran Dengan Meningkatkan Pendapatan Melalui Media Sosial.

Di akhir kegiatan pengabdian masyarakat tersebut kami melakukan evaluasi dengan cara memberikan koesioner dengan responden kurang lebih 10 orang untuk melihat presentase tingkat kepuasan peserta selama mengikuti kegiatan pengabdian masyarakat serta untuk mengukur secara kuantitatif presentase pengaruh dan dampak yang ditimbulkan setelah selesai mengikuti pelaksanaan kegiatan tersebut. Setelah proses evaluasi, kami akan melihat reaksi dan resposif dari peserta selanjutnya akan menyusun program berkelanjutan yang nantinya akan direncanakan oleh kelompok kami dengan tema yang berbeda serta selalu memonitoring perkembangan pegawai berikutnya.

\section{HASIL DAN PEMBAHASAN}

Jejaring sosial merupakan struktur sosial yang dibentuk dari simpulan-simpulan (yang umumnya adalah individu atau organisasi) yang diikat dengan satu atau lebih tipe relasi spesifik seperti nilai, visi, ide, tema, keturunan, dan lain-lain.

Perubahan komunikasi konvensional menjadi modern dan serba digital, menjadikan semakin pesatnya perkembangan teknologi. Jejaring sosial merupakan media secara online yang dapat digunakan siapapun, kapanpun dan dimanapun. Selama fasilitas mendukung maka media sosial bisa digunakan. Semua orang di era milenial sekarang, tidak bisa terlepas dari yang namanya media sosial. Semua orang menggunakan media sosial untuk 
berbagai kepentingan baik untuk bekerja, bercengkrama dengan keluarga atau teman, bertemu teman lama dan bahkan untuk berbisnis.

Kehidupan manusia di dunia yang semakin maju seiring dengan perkembangan teknologi, termasuk dalam perkembangan teknologi komunikasi. Sehingga membuat manusia dengan kebutuhan komunikasinya sangat dimanjakan oleh perkembangan teknologi komunikasi yang semakin pesat. Perkembangan ini memberikan banyak kemudahan bagi manusia dalam melakukan komunikasi, salah satunya adalah komunikasi melalui media internet. Melalui media internet, arus komunikasi menjadi sangat terbuka dan tidak memiliki batas tertentu. Semua manusia di dunia bisa saling berinteraksi tanpa harus bertatap muka. Sehingga memberikan kemudahan bagi manusia untuk bersosialisasi dengan sesama tanpa ada halangan ruang dan waktu. Pada saat ini, dalam internet terdapat satu teknologi yang sedang sangat populer yaitu situs jejaring sosial. Situs yang didesain untuk mempererat hubungan antar manusia, baik itu antara teman-teman lama, temanteman baru, relasi bisnis maupun untuk memasarkan produk. Perkembangan teknologi ini membawa pengaruh ke dalam dunia komunikasi, salah satunya adalah mengenai perkenalan Identitas perusahaan. Dalam upaya untuk memperkenalkan perusahaan diperlukan adanya identitas perusahaan. Identitas perusahaan adalah sebuah identitas dari perusahaan yang membedakan dengan perusahaan lain. Identitas perusahaan adalah sebagai suatu kumpulan karakteristika suatu perusahaan yang saling tergantung, memberikan specifitas, stabilitas, dan pertalian, sehingga bisa didefinisikan.

Sebagai media yang bisa diakses oleh banyak orang, pebisnis memanfaatkan hal ini untuk membuat sebuah strategi promosi atau strategi untuk bisnis yang bisa dikatakan gratis tanpa dipungut biaya. Dalam perkembangannya, jejaring sosial dibuat dan dioperasikan dengan memiliki satu fokus, yaitu memperkenalkan identitas perusahaan. Semua identitas perusahaan, yang telah dipublikasikan melalui jejaring sosial adalah nama, gaya, logo, dan slogan. Semua diperkenalkan melalui pesan teks ataupun gambar. Tidak ada jadwal pasti mengenai kapan mengoperasikan jejaring sosial, atau dengan kata lain pada waktu luang saja.

Jejaring sosial tidak hanya digunakan untuk kegiatan komunikasi di dunia maya saja, blog, forum diskusi atau aktivitas yang lain. Namun, situs jejaring sosial juga dapat digunakan untuk kegiatan yang bersifat komersial, bisnis, dan dapat menghasilkan keuntungan di dalamnya. Dengan memanfaatkan medsos sebagai sarana komunikasi tanpa batas waktu dan ruang.
Berikut merupakan beberapa situs jejaring sosial yang paling sering digunakan untuk mendorong kinerja dan meningkatkan keuntungan bagi sebuah bisnis. Sehingga, untuk kedepannya, anda dapat memanfaatkan situs jejaring sosial dengan baik dan tepat.

Saat ini, Instagram merupakan salah satu social media paling populer, terutama bagi pengguna internet di Indonesia. Dengan total pengguna aktif mencapai 61 juta orang. Dengan rata - rata usia yang aktif menggunakan platform ini adalah berada di rentang $18-24$ tahun.

Kelebihan dan fitur yang dimiliki oleh Instagram terletak pada Instagram story, feed, dan IG TV. Anda juga dapat memanfaatkan Instagram untuk kebutuhan bisnis seperti promosi produk, jasa atau layanan yang anda miliki. Selain itu, di dalam Instagram juga menyediakan berbagai fitur deteksi wajah atau filter yang menggunakan bantuan AR (Augmented Reality), sehingga dapat menghasilkan foto atau video yang menarik dan dapat dijadikan sebuah konten. Dan fitur yang paling penting untuk menunjang bisnis anda adalah Instagram ads. Dimana, anda dapat mempromosikan produk melalui layanan iklan yang tersedia. Sehingga, produk tersebut dapat menjangkau konsumen secara global dan luas.

Setelah mengetahui dampak media sosial, selanjutnya masuk pada pembahasan mengenai manfaat media sosial itu sendiri. Berikut merupakan beberapa penjelasan mengenai manfaat media sosial.

1. Mendapatkan informasi secara actual Membagikan berbagai konten terbaru sangatlah mudah dilakukan saat ini. Karena, sekarang banyak sekali aplikasi social media yang dibuat untuk membantu proses pencarian berbagai sumber informasi dalam setiap bidang kehidupan. Informasi tersebut berasal dari berbagai daerah di seluruh penjuru dunia.

2. Mampu berkomunikasi secara real - time Apakah anda sering menghabiskan waktu untuk melakukan percakapan dengan teman, saudara, dan yang lainnya dengan menggunakan platform media sosial? JIka benar, maka percakapan atau biasa disebut chatting merupakan bentuk komunikasi yang dapat dilakukan secara real - time (langsung). Manfaat utama dari medsos adalah untuk memutus jarak dan waktu dalam penyampaian informasi dari satu pihak ke pihak lain. Sehingga, informasi tersebut dapat tersampaikan secara langsung, meskipun berbeda wilayah dan berjauhan.

3. Meningkatkan brand awareness

Saat kemunculan anda di dalam media sosial, anda dapat lebih mudah untuk terhubung 
dengan pelanggan. Sebaliknya juga, pelanggan dapat terhubung dengan lebih mudah. Dengan adanya medsos juga dapat meningkatkan loyalitas konsumen pada brand yang anda miliki.

4. Meningkatkan trafik dan peringkat pencarian Semakin anda aktif dan rajin untuk mengupdate informasi dan konten terbaru pada situs jejaring sosial, maka akan memberikan efek yang sama untuk website anda, yaitu peningkatan trafik pengunjung. Apabila anda mempromosikan artikel atau blog website melalui medsos, maka semakin besar untuk pengunjung membaca blog anda dari tautan yang telah anda kirim. Jadi, pastikan untuk selalu menyisipkan atau menambahkan fitur sharing pada artikel website.

5. Membangun relasi dengan cepat dan luas Manfaat media sosial terakhir adalah mengembangkan jaringan atau relasi secara luas. Jika produk anda semakin dikenal oleh banyak orang, maka semakin tinggi juga trafik yang dapat anda peroleh. Membangun relasi sangatlah penting, karena bisnis akan mudah dan cepat berkembang karena terdapat sebuah jaringan yang luas, serta media promosi yang tepat sesuai dengan target pasar yang dituju.

Untuk para pelaku usaha tentu masih bingung dan terkendala dengan bagaimana menggunakan jejaring sosial untuk mengenalkan dan mempromosikan bisnis. Padahal caranya sangatlah mudah dan tentu saja semua orang bisa melakukannya.

1. Tinggal memilih media sosial jenis apa yang ingin digunakan, dari sekian banyak media sosial ada yang bersifat "public" atau umum sehingga bisa dilihat dan digunakan siapapun seperti Instagram dan Google Bisnis.

2. Selanjutnya pilih produk yang ingin dipromosikan, atau misalnya ingin seluruh usaha yang dipromosikan maka siapkan bahan promosi seperti produk unggulan, keunggulan usaha, harga, persaingan, kelebihan dan hal lain yang dianggap membanggakan usaha.

3. Apabila rencana sudah diketahui dan sudah dibuat, bisa langsung mengerjakannya di media sosial dan juga mempromosikan ${ }^{3}$. selayaknya katalog hidup yang bisa diakses dimanapun berada.

Berbisnis dengan jejaring sosial juga ada ketentuannya, tentu tidak boleh sembarangan dan harus mengikuti aturan. Hal yang harus diketahui adalah, bagaimana aturan tersebut mengarahkan para pebisnis untuk menggunakan media sosiał. yang layak untuk usaha dan ajang promosi5. Tentunya jangan sampai berlebihan dan juga membahayakan usaha serta membawa ke dalam hal-hal yang menjurus pada gagalnya usaha.
Berhati-hati dalam bertindak dan menggunakan media sosial. Meskipun bersifat bebas, jika salah langkah maka akan ada pihak yang harus bertanggung jawab dan merasa dirugikan.

Jaman sekarang tidak semua orang menggunakan televisi sebagai alat untuk mengetahui berita, namun media sosial terutama ponsel pintar sudah menjadi segalanya untuk bisa mengakses fasilitas lainnya. Salah satu kelebihan inilah yang bisa dimanfaatkan untuk usaha. Dimana media sosial bisa mempromosikan usaha dan produk lebih luas dan lebih besar lagi. Apalagi adanya jasa ekspedisi atau kurir pengantar barang semakin memudahkan para konsumen untuk membeli barang tanpa harus pusing atau ribet pergi keluar dan membeli barang di toko. Mereka tinggal mengeluarkan uang dan akhirnya sampai ke tempat.

Setelah mengetahui berbagai jenis media sosial yang sering digunakan untuk membantu kebutuhan bisnis, selanjutnya kita masuk pada penjelasan mengenai dampak media sosial bagi pengguna aplikasi. Berikut merupakan beberapa dampak yang ditimbulkan dalam pemakaian social media.

Berikut merupakan dampak positif dari penggunaan medsos ditinjau dari segi bisnis.

1. Meningkatkan keuntungan dari penjualan produk. Apabila anda sering mempromosikan produk anda melalui iklan atau postingan, maka berpeluang besar untuk mendapatkan trafik pengunjung untuk membeli dan menggunakan produk anda. Pastikan untuk selalu memberikan informasi produk sedetail mungkin untuk meningkatkan kepercayaan customer.

2. Meningkatkan kredibilitas perusahaan atau organisasi. Selanjutnya, kredibilitas perusahaan dapat diukur dari seberapa besar dan banyaknya sebuah perusahaan memberikan layanan dan produk yang berkualitas dan dibutuhkan oleh customer. Dengan memanfaatkan media sosial, anda juga dapat menyusun profil perusahaan untuk membantu produk penjualan dan pemasaran barang atau jasa.

Menjalin kerja sama bisnis secara luas Semakin kredibilitas anda meningkat, semakin timbul banyaknya relasi dan jaringan yang terhubung secara cepat melalui aplikasi medsos. Kerja sama, umumnya akan dilakukan dengan diskusi antar founder perusahaan terkait. Anda dapat mencoba menggunakan fitur medsos untuk membantu kerja sama tersebut.

Secara umum ada 5 hal yang bisa dilakukan untuk meningkatkan pengunjung atau follower pada akun Instagram perusahaan antar lain :

1. Riset Pesaing dan produk 
2. Pahami Market produk anda

3. Optimalkan Fitur Instagram

4. Bangun CRM

5. Paid Traffic Langkah simple dan terakhir .

Menggunakan social media bisa jadi memang menyenangkan. Namun, untuk pemilik usaha yang ingin menjalankan social medianya secara efektif sebagai media promosi perlu lebih kritis dalam memilih social media yang digunakan. Jangan karena sekarang sedang hits menggunakan instagram, lantas ikut-ikutan menggunakan padahal produk yang dijual tidak sesuai. Contoh, jika Anda adalah pemilik usaha pupuk untuk tanaman, pilihan menggunakan blog atau website di rasa lebih tepat dari pada menggunakan media social instagram atau twitter untuk promosi. Upaya yang bisa dilakukan memberikan beberapa tips dalam melakukan promosi efektif melalui social media, yakni :

1. Kenali terlebih dahulu siapa target market dari produk.

2. Pilih social media yang sesuai dengan target market tersebut.

3. Optimalkan konten di social media mulai dari gambar dan tulisan

4. Berikan informasi yang jelas terkait usaha dan produk yang dijual.

5. Lakukan secara konsisten setiap hari

Kesadaran akan penggunaan media digital untuk mengembangkan usaha sebaiknya segera dilakukan para pemilik usaha. Tentu saja, agar bisnis yang mereka jalani dapat meraih pasar yang lebih luas. Hasilnya, pendapatan akan lebih meningkat. Media digital dengan memanfaatkan internet memang dirasa lebih mudah dan murah. Namun, yang perlu diperhatikan adalah bagaimana media digital tersebut dapt digunakan secara efektif sesuai dengan goals yang diinginkan.

Media social khususnya Instagram mempunyai banyak manfaat sebagai pilihan pengusaha untuk memasarkan produk dan jasa seperti:

1. Kemudahan Mempromosikan Produk dan Layanan. Instagram menawarkan berbagai fitur fungsional untuk memudahkan Anda mengenalkan dan mempromosikan produk atau layanan Anda. Diantaranya adalah:

a. Instagram Shopping-fitur ecommerce yang memudahkan Anda membuat toko di Instagram, mempublikasikan shoppable post, menambahkan label belanja, hingga menampilkan koleksi dan detail produk.

b. Instagram Promoted Posts-promosi post akun bisnis Anda dengan menyesuaikan target audiens, besaran budget, serta durasi waktunya. c. Shoppable Tags di Instagram Storiestak hanya di post, Anda juga bisa menambahkan shoppable tags Instagram stories untuk menampilkan dan mempromosikan produk Anda.

d. Link di Instagram Storiesmenampilkan link Swipe Up atau See More untuk mengarahkan audiens ke halaman produk atau area lainnya.

2. Kesempatan Menjangkau Audiens yang Lebih Luas. Banyak orang yang tertarik menggunakan Instagram. Merujuk kepada data dari Statista, Instagram mempunyai pengguna aktif bulanan mencapai 1 miliar dan lebih dari 500 juta orang per hari. Hebatnya lagi, pengguna tersebut rata-rata menghabiskan waktu hingga 53 menit; yang mana hampir menyamai Facebook dengan rata-rata 58 menit. Artinya, bisnis Anda mempunyai kesempatan besar untuk menjangkau audiens baru yang belum pernah mengenal bisnis Anda sebelumnya. Itulah mengapa Instagram juga dikenal sebagai salah satu platform terbaik untuk meningkatkan brand recognition dan brand awareness.

3. Meningkatkan Angka Penjualan. Tidak hanya sebatas membantu mempromosikan bisnis Anda, Instagram juga menghadirkan berbagai fitur terbaik untuk meningkatkan angka penjualan. Faktanya, sepertiga pengguna Instagram juga seringkali melakukan pembelian secara langsung melalui aplikasi ini di ponsel mereka. Berikut contoh fitur fungsional untuk meningkatkan pendapatan bisnis Anda:

a. Instagram Checkout-memungkinkan konsumen untuk melakukan seluruh proses pembelian produk langsung dari Instagram tanpa harus keluar dari aplikasi tersebut.

b. Tombol Call-to-action-mendorong audiens untuk melakukan berbagai tindakan yang Anda inginkan; mulai dari memesan makanan (order food), menjadwalkan perjanjian, membuat reservasi, membeli tiket, dan sebagainya.

4. Mengoptimalkan Visibilitas Online Anda . Dengan strategi yang tepat, Instagram bisa dimanfaatkan untuk mengoptimalkan visibilitas online Anda. Sebagai contoh, Anda dapat menggunakan hashtag untuk membuat konten Anda semakin mudah ditemukan di halaman explore Instagram. Kemudian bagi akun bisnis, Instagram juga menawarkan elemen tambahan yang akan membuat profil Anda terlihat semakin profesional dan memikat hati audiens. Diantaranya adalah seperti kategori bisnis, info kontak, website, dan call-to-action. Kabar baiknya, hampir semua pengguna Instagram menyukai akun bisnis. 
Untuk membuktikannya, mari perhatikan beberapa data berikut: $90 \%$ akun Instagram setidaknya mengikuti satu akun bisnis Setiap harinya, 200 juta pengguna Instagram mengunjungi minimal profil satu akun bisnis. Satu dari tiga stories yang mendapatkan jumlah views terbanyak adalah dari akun bisnis. $62 \%$ orang menjadi semakin tertarik dengan suatu bisnis atau produk setelah melihatnya di Instagram stories.

5. Membangun Hubungan Baik dengan Customers Instagram mempunyai engagement rate yang lebih tinggi dibandingkan platform lainnya, yakni mencapai 3\%. Oleh sebab itu, Anda dapat memanfaatkannya untuk berinteraksi dan mempererat hubungan Anda dengan para pelanggan. Mulai dari sekedar menjawab keluh kesah mereka di kolom komentar, membangun komunitas melalui hashtag, memposting pertanyaan di stories, hingga memaksimalkan user-generated content (UGC)—semuanya akan membangun hubungan jangka panjang yang baik dengan audiens dan mendorong mereka untuk menjadi follower yang loyal.

6. Mengenali Siapa Customers Anda

Tak kalah pentingnya, Instagram bisa membantu Anda mengenali customers Anda dengan lebih dalam. Pasalnya, Instagram hadir dengan fitur Analytics yang memuat data demografi dan perilaku audiens Anda. Beberapa data yang bisa Anda analisis meliputi usia, jenis kelamin, lokasi, konten mana yang paling disukai followers, akun apa saja yang mereka ikuti, dan sebagainya. Seluruh informasi tersebut tidak hanya bisa menjadi referensi yang sangat bermanfaat untuk membuat rencana konten Instagram, namun juga untuk mengembangkan strategi kampanye marketing bisnis Anda secara keseluruhan.

Selain itu, hashtag Instagram juga dapat membantu Anda dalam meningkatkan jangkauan pasar, terhubungan dengan praktis dengan target audiens dan membangun kesadaran merek (brand awareness). Untuk itu, kami akan membantu Anda bagaimana meriset hashtag dan memilih hashtag Instagram yang mampu membawa hasil maksimal terhadap marketing bisnis Anda di Instagram.

1. Lakukan Analisa Hashtag Secara Menyeluruh. Langkah pertama ini perlu dilakukan secara cermat dan menyeluruh. Pertama, Anda harus melakukan riset hashtag Instagram dari segi pemasarannya. Tipsnya, Anda bisa mencari apa yang sedang tren saat ini yang berkaitan dengan bisnis Anda. Misalnya, Anda memiliki bisnis fashion, Anda bisa meriset hashtag Instagram dari segi marketing seperti \#koreanfashion, \#jualbajufashionkorea dan semacamnya.

Setelah itu, Anda meriset akun-akun kompetitor yang memiliki bisnis serupa dengan Anda. Cari tahu hashtag apa yang biasa mereka gunakan dalam setiap postingannya. Catat dan uji coba terhadap konten postingan Anda. Anda juga bisa menggunakan aplikasi penunjang Anda dalam mempermudah analisa hashtag Instagram contohnya seperti Viral.

2. Buat Hashtag Merek Sendiri dan Gunakan Secara Konsisten. Langkah riset hashtag yang kedua akan lebih menjurus pada Anda yang ingin membangun kesadaran merk di benak masyarakat atau biasa disebut dengan brand awareness. Buatlah nama produk atau toko onlinemu seunik mungkin namun tetap simple dan mudah untuk masyarakat cari.

3. Cari Hashtag Paling Banyak Dicari Audiens. Bukan cuma kata kunci yang harus sesuai dengan SEO (Search Engine Optimization), pencarian hashtag Instagram juga harus mengandung SEO tinggi alias Anda harus mampu meriset hashtag apa yang biasanya sering orang cari terkait dengan produk Anda.

4. Kombinasikan Seluruh Hashtag. Setelah melakukan riset dan membuat hashtag Instagram merek bisnis Anda sendiri, selanjutnya Anda kombinasikan seluruh hashtag tersebut ke dalam satu konten postingan yang akan Anda promosikan di Instagram. Setelah itu, tinggal tunggu engagement yang akan dihasilkan dari penggunaan hashtag yang telah Anda riset sebelumnya.

5. Uji Coba Hashtag dengan Strategi 10/10/10 .Idealnya, penggunaan hashtag biasanya terbatas namun tidak kurang dan tidak juga terlalu banyak. Biasanya yang dianjurkan berjumlah 11 hashtag untuk setiap konten postingan. Ini menghindari agar pembeli tetap bisa fokus pada main caption konten Anda. Namun, ada strategi lain yang bisa dilakukan untuk memperkuat hasil dari penggunaan hashtag Instagram. Yakni dengan menggunakan teknik 10/10/10 dimana Anda menggunakan 30 hashtag untuk satu konten yang terdiri dari 10 hashtag demografi bisnis Anda, 10 hashtag umum yang biasa dicari orang dan 10 hashtag yang terkait dengan kesukaan niche market Anda.

Itulah langkah yang perlu Anda lakukan dalam mengoptimalkan penggunaan hashtag Instagram untuk hasilkan konversi yang tinggi. Hashtag Instagram adalah bagian penting dari pemasaran online, jadi usahakan Anda menggunakannya dengan benar dan maksimal. tak terkecuali 
pembelajaran mengenai cara meriset dan memilih hashtag Instagram yang baik dan benar.

\section{PENUTUP}

\section{Simpulan}

Berdasarkan hasil kegiatan Pengabdian Masyarakat dapat diambil kesimpulan bahwa pemanfaatan media sosial dalam memasarkan produk sangat penting untuk meningkatkan pendapatan perusahaan. Di masa pandemi Covid 19 yang sampai saat ini belum juga berakhir, banyak pelaku usaha yang mengalihkan kegiatan pemasarannya dari offline menjadi online. Simpulan menyajikan ringkasan dari uraian hasil dan pembahasan, mengacu pada permasalahan mitra. Berdasarkan kedua hal tersebut, uraikan faktor pendukung dan penghambat kegiatan.

Kegiatan yang dilaksanakan memberikan kontribusi pada peningkatan pengetahuan dan keterampilan tentang memanfaatkan media sosial dalam memasarkan produk untuk meningkatkan pendapatan perusahaan. Materi yang telah disampaikan diharapkan dapat memberikan peningkatan pengetahuan dan pemahaman untuk selanjutnya dapat diterapkan oleh mitra dalam kegiatan usaha. Semoga manfaat dari kegiatan ini bisa berdampak pada perubahan cara pandang bagi pegawai pemasaran yang mulai berfikir untuk terus beradaptasi dalam perubahan era saat ini dengan memanfaatkan media sosial dalam memasarkan produk untuk meningkatkan pendapatan perusahaan.

\section{Saran}

Sebagai saran, banyak pilihan jejaring sosial yang dapat digunakan sebagai pada platform media social untuk pengembangan perusahaan dengan menggunakan media-media sosial seperti Facebook, Instagram, Youtube, Linked In dan Google My Bussines. Selain gratis, media ini mudah untuk digunakan dan tentunya dapat digunakan untuk mendukung kegiatan memasarkan produk atau jasa perusahana.

Saran disusun berdasarkan analisis keunggulan dan kelemahan atau hal yang sudah dan belum tercapai dari kegiatan serta keberlanjutan kegiatan.

\section{Ucapan Terima Kasih}

Atas perhatian dan kerjasama semua pihak yang telah berperan aktif serta membantu atas terselenggaranya kegiatan Pengabdian Masyarakat ini, kami menghaturkan terima kasih.

\section{E. DAFTAR PUSTAKA}

Kartajaya, H., \& Marketeers, T. R. (2018). CITIZEN 4.0: Menjejakkan Prinsip-Prinsip Pemasaran Humanis di Era Digital. Gramedia Pustaka
Utama.

Kotler, P., Kartajaya, H., \& Setiawan, I. (2019). Marketing 4.0: Moving From Traditional To Digital. In Gramedia. PT. Gramedia Pustaka Utama. https://doi.org/10.1142/9789813275478_0004

Suleman, D., Ali, H., Nusraningrum, D., \& Ali, M. M. (2020a). Consumer Factors in Choosing Shopping Place in 4.0. JURNAL MANAJEMEN DAN BISNIS SRIWIJAYA, 17(4), 193-198. https://doi.org/DOI: https://doi.org/10.29259/jmbs.v17i4.11529

Suleman, D., Ali, H., Nusraningrum, D., \& Ali, M. M. (2020b). Strategi memenangkan persaingan bisnis berbasis perilaku konsumen untuk produk fashion. Lembaga pendidikan dan pelatihan balai insan cendekia.

Suleman, D., Ali, H., Nusraningrum, D., \& Ali, M. M. A. (2019). Perceived Ease of Use, Trust and Risk toward Attitude and Intention in Shopping for Online Fashion Products In Indonesia. Archives of Business Research, Vol.7(No.4), pp.240-253. https://doi.org/DOI: http://dx.doi.org/10.14738/abr.74.2019

Suleman, D., Sabil, S., \& Suharyadi, D. (2021). Mengenali Perilaku Konsumen dan Konsep Strategi Pemasaran (berbasis teori dan pendekatan praktis). Insan Cendekia Mandiri.

Sumawan, U. (2002). Perilaku konsumen: Teori dan Penerapannya dalam Pemasaran. Pt. Ghalia Indonesia dengan MMA-IPB.

Kartajaya, H., \& Marketeers, T. R. (2018). CITIZEN 4.0: Menjejakkan Prinsip-Prinsip Pemasaran Humanis di Era Digital. Gramedia Pustaka Utama.

Kotler, P., Kartajaya, H., \& Setiawan, I. (2019). Marketing 4.0: Moving From Traditional To Digital. In Gramedia. PT. Gramedia Pustaka Utama. https://doi.org/10.1142/9789813275478_0004

Suleman, D., Ali, H., Nusraningrum, D., \& Ali, M. M. (2020a). Consumer Factors in Choosing Shopping Place in 4.0. JURNAL MANAJEMEN DAN BISNIS SRIWIJAYA, 17(4), 193-198. https://doi.org/DOI: https://doi.org/10.29259/jmbs.v17i4.11529

Suleman, D., Ali, H., Nusraningrum, D., \& Ali, M. M. (2020b). Strategi memenangkan persaingan bisnis berbasis perilaku konsumen untuk produk fashion. Lembaga pendidikan dan pelatihan balai insan cendekia.

Suleman, D., Sabil, S., \& Suharyadi, D. (2021). Mengenali Perilaku Konsumen dan Konsep Strategi Pemasaran (berbasis teori dan pendekatan praktis). Insan Cendekia Mandiri.

Sumawan, U. (2002). Perilaku konsumen: Teori dan Penerapannya dalam Pemasaran. Pt. Ghalia Indonesia dengan MMA-IPB. 